\title{
Mature Testicular Teratoma
}

National Cancer Institute

\section{Source}

National Cancer Institute. Mature Testicular Teratoma. NCI Thesaurus. Code C6355.

A teratoma that arises from the testis and is composed of well differentiated, adult-type tissues. 